\title{
The phenomenon of bullying in junior high school students nowadays
}

\author{
Addini Nurlia $^{\text {a,1,*, }}$, Siti Partini Suardiman ${ }^{\text {a,2 }}$ \\ ${ }^{\text {a }}$ Program Studi Bimbingan dan Konseling, Program Pascasarjana Universitas Negeri Yogyakarta.Indonesia \\ ${ }^{1}$ addininurlia1992@gmail.com; ${ }^{2}$ sitipartini@gmail.com \\ * corresponding author
}

ARTICLE INFO

Article history

Received 2019-10-29

Revised 2019-11-17

Accepted 2020-02-05

Keywords

Phenomenon

School bullying

Verbal bullying

Physical bullying

Cyberbullying

\section{ABSTRACT}

Bullying is one of the most aggressive attitudes and violence between peers in the school environment. This research aims to determine how the phenomenon of bullying is happening at this time, especially in junior high school students. This research using qualitative methods, data collected by interview techniques. The research subject is counseling guidance teachers at junior high school. The object in this research is one of the junior high school in Yogyakarta. The study's findings are that junior high school students conduct verbal bullying behavior, physical bullying, and cyberbullying. There are several factors of bullying: behavior within seniority, the history of being a victim of bullying, economic status, violence from the media, family, and peer factors. The impact of bullying behavior can be felt for victims and the more bully or people who do the bullying.

This is an open access article under the CC-BY-SA license.

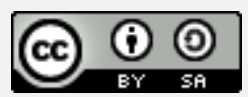

\section{Introduction}

Bullying is one of the aggressive behaviours and violence among peers in the school environment. The three signs of someone doing bullying behaviours: the ability of a person to do different behaviour or to show something different from them, the activity of repetition of negative and an imbalance behaviour. The findings are based on interviews conducted by researchers on counselling guidance Teachers (BK) in one of the Junior High School (SMP) in Yogyakarta, obtained by $40 \%$ to $45 \%$ of students do Verbal bullying by making fun of their friends. The findings above are in line with the findings of [1]. it mentions an average of 33\% of school-age students between 13 and 15 years reported being victim of bullying, in North America and European 31\% of teenagers aged 11-15 years old Intimidate friends at school. Male students and female students do bullying behaviour at school, although their behaviour are doing differently, boys are physically bullying, while girls suffer verbal bullying that happens directly or orally. Personal characteristics of bullyer, as being arrogant and narcissistic, are often referred to as excuses, while some bullyers use intimidation as a way to conceal the lack of their pride. The behaviour of students who tend to be influenced by the development of technology that knows the Internet, without the control of parents usually the child will be do bullying from social media [2].

There are several factors of bullying behaviour such as: (a) bullying behaviour is performed by seniors as a form of senior power to the junior with the aim of superiority that helps individuals higher than the other. In line with the findings of the field shows the form of physical bullying that occurs in students conducted by seniors against Junior in a school with physical contact such as hitting; (b) bullying caused by a family condition or a family which not in peace situation.it easy for the children to do aggressive behaviour. The findings of the field showed a harmonious family factor in the lack 
of attention and love given by parents to children become one of the children's factors to be a bullyer in the school; (c) bullying caused by school condition or education that is not harmonious and discriminatory. This is in line with the findings in society showing the seniority that occurred in the continuous progress, where the victims of bullying will become the bullyer when they are already a senior. According to the results of the interview shows the verbal bullying that occurred in the form of making fun, giving the nickname an inappropriate name and deliberately exclusion of other friends [3].

The impact of bullying behaviour is not only happened to the victim but also happened to the bullyers. Bullying that is done verbally or physically carries serious harm to the students involved in either victims ' bullying or bullyers, such as psychological problems experiencing high levels of depression, self-esteem being low, and anxiety [4]. In generally the victim is an individual who experiences all negative social, academic, and personal impacts that can impede normal personality growth and personal development in society, there are also some negative effects as a result of bullying for bullyers who can be felt if their behaviour is not handle yet which can ultimately lead to some tendencies of adolescent criminal behaviour [5]. The findings in society explaining the victims of bullying will be afraid and uncomfortable to be in the school, while the severe cases of bullying will be to drop out from the school.

Bullying can happen directly and indirectly, according to Farrington and Ttofi bullying directly refers to the real contact that is directly by the bullyers to their victim, such as biting, Pushing, hitting, or calling the name. According to Greeff \& Grobler's indirect bullying, as its name suggests, involves less immediate behaviour such as spreading rumors about someone. Along with recent advances in digital technology has allowed bullies to enter the virtual world. According to Fousiani, et al Cyberbullying can be defined as deliberate, aggressive, and, most importantly, repeatedly harassing individuals or groups of individuals using electronic media (i.e., mobile phones, tablets, and Computer). In generally students who do bullying is depicted in four categories: physical bullying, verbal bullying, social bullying, and cyberbullying. Physical Bullying is by injuring another person's body or damaging another person's stuffs. Verbal Bullying is with the use of words to make emotional pain such as painful comments, humiliation, and ridiculing. Social Bullying involves behaviours intended to sabotage or impair a person's social position or reputation; Examples are dangerous rumors and social exclusion. Cyberbullying includes the use of electronic or digital communications to intimidate others; it is often via email, text messaging, and social media sites [6].

Based on the explanation that has been shown above, this research aims to know how the phenomenon of bullying that is happening in the school at this time especially in SMP students. This research was done because of the ongoing bullying behaviour in the school and has not shown a significant number of behavioural decline. By knowing how exactly the phenomenon of bullying that is happening in school is expected to further researchers have a picture of bullying behaviour and can minimize the bullying behaviour that is happening in the school.

\section{Method}

This research uses qualitative methods. Qualitative research methods do in a natural condition. Qualitative research methods are used to obtain deep data, a data that contains meaning. Meaning is the exact data that is a value behind the data that appears. This research aims to obtain an overview and also information about the phenomenon of bullying behaviour in junior high school (SMP) students in Yogyakarta. The method of data that is applied in this qualitative study using unstructured interview techniques for data collection. The interview is a meeting of two people to exchange information and ideas through question and answer, so it can be contracted to meaning in a particular topic. Interview techniques have three kinds of structured interview ways, semistructured interview and unguided interview. For the collection of data on the authors using unstructured interview, unstructured interview is a free interview where researchers do not employ a systematic and complete and detailed interview guideline to collect His data. In this study the interview guidelines used are only the outlines that are asked. The subject of this study was BK teachers or guidance counselling teachers junior high school in Yogyakarta City. The object in this research is one of the junior high school in Yogyakarta. The limitation of this research does not list the identity of schools and teachers of BK teachers is in a clear state to appreciate the subject of research that is in school institutions. The data analysis in this study is using the Miles and Huberman model. Data analysis in qualitative 
research is conducted at the time of data collection, and after completion of data collection in a certain period. Miles and Huberman find that activities in the analysis of qualitative data are done interactively and continue continuously until complete, so that the data has been saturated [7].

\section{Results and Discussion}

Based on the results of interviews with guidance and counseling teachers on Table 1. the authors highlight four aspects of bullying behavior in students at school, first about the types of bullying that occur in students, the second about the factors that cause students to bullying, the third about the impact of student bullying behavior, and the Finally, regarding the efforts made by the guidance and counseling teacher to minimize bullying behavior at school.

Table 1. Interview result

\begin{tabular}{l}
\hline The Aspects \\
\hline What kind of \\
bullying \\
students ofte \\
do
\end{tabular}

What factors cause students to do bullying

\section{What happened to the student bullying behavior}

\author{
What are the \\ efforts that \\ have been done \\ by BK teachers \\ to minimize \\ bullying at \\ school
}

The types of bullying by students are:

(1) Verbal Bullying. Verbal Bullying is a bullying behavior by students to making fun of other students with inappropriate calls, this happens to classmates and also happens between seniors to junior. In addition, there are some students who deliberately exclusion other friends from the association by forming their own groups.

(2) Physical bullying that takes place between seniors and their junior, bullying involving a physical touch by hitting or fighting. This physical Bullying can be detected by the teacher after the parents who have been victims give complaints to the school.

(3) Cyberbullying using social media. Cyberbullying happens with the way students create social media status with the goal of insulting other students.

Students bullying occurs because of several factors:

(1) Students bullying because of seniority, the older class feels stronger and more powerful and can bully the junior. This seniority will continuously occur where students who are victims of bullying could potentially retaliate by doing the same bullying to his junior.

(2) Previously became the bully victim of the senior or class brother. This happens because the bullyers feels reasonable to take revenge on the junior.

(3) Feeling the economic status of bullyers is higher than the victims, this is what makes them feel free to do anything to students whose economic status is lower.

(4) The impression of violence that they can see from social media, television shows or video games.

(5) Family factor, families who are less concerned about children's activities in the school and the less harmonious family such as families whose fathers and mothers commonly see verbal or physical violence in front of children will make children naturally if they do Violence to others.

(6) The influence of peers, not a few bullyers in the group do bullying in groups in the sense of inviting other friends, as well as not a few students ' behavior that is being seen by other students and made an example.

The impact of bullying behavior can be felt for victims of bullying as well as the bullyer.

(1) The impact that occurs for students who are victims of bullying, i.e. students feel insecure to be in school and classroom and even students become reluctant to attend the schools because they are victims of bullying, in the victim will arise feelings of fear of being Victims of bullying again.

(2) For physically bullying events students have to exercise treatment at home because they suffer from fights, this causes students to miss the lesson. Victims of bullying in the future also potentially become bullyers, can be seen from the occurrence of seniority in the school, victims of bullying tend to also bullyers when they are already a senior.

(3) The impact of bullying behavior is also happening for bullyers. From the findings can be find students who become bullyers that occur physically or who are involved heavy fights will be drop out from school. This is done when the teachers of BK, the school and the parents performed a conference case

The efforts that have been done by the BK teachers to minimize that bullying by giving classical guidance, group guidance, and giving a verbal direct rebuke to students who become bullyers. In severe cases of physical bullying and fights that occur senior and junior, the BK teachers and the school conduct a case of contingency and give sanctions drop out from the school for physically bullying. 
The results of interviews showed the types of bullying act by students are verbal bullying, such as insulting and giving or calling inappropriate nicknames and deliberately isolating other friends. Meanwhile, physical bullying occurs by hitting and cyberbullying occurs on social media such as by posted social media status with the aim of teasing the victim. Bullying can be physical, such as punches, kicks, slaps, pushes, and other physical attacks. Table 1. provides information about bullying behavior in junior high school students. The non-physical bullying divided into two, namely verbal and nonverbal. Mockery, calls with bad titles, threats, spreading the victim's secret news, and embarrassing words, are classified as verbal action. Unpleasant facial expressions and threatening body language are nonverbal actions. So, the act of bullying makes the perpetrators more dare to act more recklessly towards victims which may lead to severe criminal acts, while the victim feels low of self-esteem, insecure and unhappy [8]. In line with research by Antiri in Ghana, 37.2\% of respondents stated that verbal bullying occurs at their school, $40.6 \%$ of perpetrators stated that they had committed verbal bullying, $36.4 \%$ of victims stated that they were verbally bullied, while $35.5 \%$ of other students stated that they had witnessed verbal bullying [9]. Marela Gitry, et al, found that adolescents experienced more verbal bullying compared to other types of bullying. Adolescents experience verbal bullying due to called by inappropriate names, often insulted by friends, and in the relevant study, found that cyberbullying experience had an incidence of at least 3\% [10]. The cyberbullying incident must be watched out because it occurs indirectly and the perpetrators can disseminate faster to make the victim more depressed. In line with Barger's explanation in [11], physical bullying is categorized as hitting, kicking and other physical activities. Physical bullying can harm victims, for example, in Chicago, a teenager commits suicide after being a victim of physical bullying. Bullying behavior acted by students occurs continuously. There is self-satisfaction for the perpetrators when successfully oppressing the victim. Bullying behavior, such as disturbing victims of bullying, is interpreted as a feeling of pleasure so that they have the desire to act bully or disturb the victims bullying in the next future [12].

Other findings regarding the factors that cause students to bully are: (1) Seniority, this is in line with the opinion of Astuti (Usman), who states that seniority as a bullying behavior and often actually expanded by students as latent occurrences. Seniority is usually continued for entertainment, channeling revenge, jealousy, or seeking popularity, as well as a continuing tradition or showing power [13]. This behavior is exacerbated by the unclear actions of teachers and school administrators. Some teachers tend to allowed, while others forbid it; (2) history of being a victim of bullying also found out by Sari \& Azwar. The reasons of bullying act is, the victims have the perceptions toward the bullying perpetrators, such as of tradition, revenge for being treated the same (according to male victims), showing power, angry because the victim did not behave as expected, getting satisfaction (according to male victims), and jealousy (according to female victims) [14]. The victims also perceive themselves to be a victim because of flashy appearance, not behaving appropriately, rude behavior, and tradition; (3) economic status, this factor contradicts to Geres, et al which stated that there no relationship was found between wealth and bullying behavior in women. This study also found that male bullies perpetrator were significantly richer than victims, although, statistically, the significant differences were very small [15]; (4) a television show on violence, Gentile and Bushman conducted Experimental studies that showed violence shown on media causes people to immediately act more aggressively after seeing it. Experimental studies have been criticized for being somewhat artificial, but field experiments have produced similar results in more realistic settings. However, it is not a direct effect of violence show, but rather a long-term effect. Longitudinal studies proved the relationship between violence show seen by a child and behavior of aggressive and violent that will emerge the years later at adolescence phase [16]; (5) family factors. In line with Zakiah, et al, the family can also be a factor in a teenager becoming bullied or act bullying, for example, the poor relationship between children and parents. Teenagers may lose attention at home, so they seek attention at school by showing power over others who are considered weaker. Also, violence committed at home against children can be one of the reasons why someone becomes bullied. Bullying perpetrators act as an interpretation of an escape from home that always presses and makes him helpless; (6) peers, in line with Masdin, one of the big factors of bullying behavior in adolescents is peers who give a negative influence by spreading the idea (both actively and passively) that bullying is not a big problem and is a reasonable thing to do In this time, adolescents had a desire to no longer depend on their families and began to seek support and a sense of security from their peers [17]. 
The next finding related to the impact felt by students from bullying behavior. The results of interviews showed; students feel afraid of being victims of bullying in the next future and feel insecure. Some students feel uncomfortable in class. And, there are even students who do not want to go to school. Meanwhile, the physical impact of bullying causes students to get injured and miss the study because they have to undergo treatment at home. The impacts of bullying experienced by students are loss of self-esteem, anxiety, stress, depression, difficult to concentration in learning process at school, do not want to go to school, and, in cases of severe bullying, the victim might have self-injured and suicide [18]. Mark Dombeck explained (Muzaffar), if the bullying continues for a long time, victims may feel insecure, begin to feel a lack of trust to others, show extreme sensitivity, or in cases of more serious bullying, begin to develop in mental illnesses such as psychopaths, avoidant personality disorder or PTSD. Victims can also have the desire for revenge, the desire sometimes arises to torture others and potentially become perpetrators of bullying in the future [19]. The effects of bullying can also affect the perpetrators themselves. Most bullying students grow up into emotional people. Adolescents who experience bullying have a 1.5 times greater chance of experiencing depression compared to adolescents who do not experience bullying. Research in the Netherlands showed that there is a relationship between bullying and health symptoms. Teenagers who experience bullying are three times more likely to experience depression than teenagers who do not experience bullying. Besides depression, a teenager with bullying will experience psychosomatic complaints such as headaches, sleep problems, stomachaches, anxiety, feelings of unhappiness, decreased appetite and bedwetting. Research in West Africa showed that bullying victims are 1.97 times more likely to experience depression than those without bullying and suicidal ideas are 1.72 times greater.

Next, efforts have been made by BK teachers to minimize bullying by providing classical guidance in class and giving verbal reprimands to students. For severe cases, such as physical bullying, BK teachers and schools hold case conferences and give sanctions expelled from schools. In short, the researchers assumed that the work of BK teacher was still lacking and needed to be improved again. Bullying in the school environment is the responsibility of the school. So, the school needs to apply rules or the right consequences for bullying behavior. In line with the opinion [20] argued that schools and teachers are responsible for bullying act in schools which usually occur due to lack of antibullying policies, inadequate teacher training, and low case-reporting as reasons behind the failure to overcome the bullying. About $30 \%$ of students stated that the teacher did not know about the bullying around. About one in six cases of bullying, the teacher does not provide intervention, does not stop and even ignores the bullying [21] Teachers are expected to be more active in supervising student activities at school and inviting parents to play an active role in preventing bullying due to the level of supervision in schools determines how much and how often bullying occurs [22]. Ulfiah suggested that the religious approach is a good way to handle the perpetrators of bullying. Religious approach counseling may provide services based on faith and piety as the main goal of education will not be achieved only through the teaching process, but also guidance counseling efforts are needed [23]. The low level of supervision at home, as well as the low level of supervision at school, is closely related to the development of bullying behavior among students. The importance of supervision is carried out especially in the playground or garden and in the school environment because, usually in both places, bullying behavior often occurs. Bullying exists in almost every school, both public and private schools. This study found that bullying in schools affects academic achievement both for victims, and, at the same time, also affects the perpetrators of bullying. This study suggests that teachers and school staff should take appropriate steps to reduce bullying [24].

\section{Conclusion}

Based on the study of the results of this qualitative study, the conclusions of junior high students conduct verbal bullying behaviour, physical bullying and cyberbullying. Bullying behaviour is in the event of several factors; Seniority, the history became victims of bullying, economic status, violent impressions from the media, family and peer factors. The impact of bullying behaviour for victims of the lack of concentration of learning is in the school, stress, anxiety and will appear a desire for victims to take revenge and on the long-term impact of bullying victims can become bullyers, in exceptional cases bullying behaviour can make someone commit suicide. The impact of bullying is not only perceived by the victim but also to the bullyers, as teenager tend to be emotionally personal. The school is expected to conduct strict supervision for bullying problems. The school to see bullying behaviour is not unusual, the need for clear intervention and punishment and proper rules for bullying. 
Exposure of qualitative studies above, is expected to be a description of the phenomenon of bullying behaviour in the school. Tutoring and counselling guidance services in the school in providing an understanding of bullying has been implemented precisely but a little less maximum. Counselling guidance teachers or BK teachers can provide students with services to lower bullying behaviour. The implications of this research are also expected to be done to reduce the behaviour of student bullying through BK media about bullying. The BK media can serve as a preventative companion media (to prevent bullying) and as a curative media-resistant (to reduce bullying behaviour that has occurred to students. The next research is expected to provide findings on the effective way to minimize the behaviour of bullying in the school that can be used in counselling and guidance.

\section{Acknowledgment}

We thank my supervisor Prof. Siti Partini Suardiman who provided insight and expertise that greatly assisted the research. However, they may not agree with all of the interpretations/conclusions of this paper. and We thank all contributors for assistance with a particular technique, methodology, and comments that greatly improved the manuscript.

\section{References}

[1] D. E. Smith and C. T. Kilpatrick, "School bullying in the Jamaican context through an ecological lens," Glob. Stud. Child., p. 204361061772373, 2017, doi: 10.1177/2043610617723736.

[2] Chadwick., Impact of Cyber Bullying, Building Social and Emotional Resilience In Schools. New York Dordrecht London.: Springer Cham Heidelberg:, 2014, doi: 10.1007/978-3-319-04031-8.

[3] Astuti, Ponny, and Retno., Meredam Bullying 3 Cara Efektif Mengatasi Kekerasan Pada Anak. Jakarta: PT Grasindoo, available at: Google Scholar.

[4] L. Steven, "Bullying among teenagers and its effects.," pp. 1-27, 2015, available at: Google Scholar.

[5] A. Asif, "Relationship between Bullying and Behavior Problems ( Anxiety, Depression, Stress ) among Adolescence : Impact on Academic Performance," pp. 1-35, 2016, available at: Google Scholar.

[6] J. Choi and N. E. Kruis, "The Effects of Life Domains on Cyberbullying and Bullying: Testing the Generalizability of Agnew's Integrated General Theory," Crime Delinq., vol. 65, no. 6, pp. 772-800, 2019, doi: 10.1177/0011128718814860.

[7] Sugiyono., Metode Penelitian Kualitatif. Bandung: Alfabeta, 2013, available at: Google Scholar.

[8] Sucipto, "Bullying Dan Upaya Meminimalisasikannya Bullying and Efforts To Minimize," Psikopedagogia, vol. 1, no. 1, 2012, doi: 10.12928/psikopedagogia.v1i1.2566.

[9] K. O. Antiri, "Types of Bullying in the Senior High Schhools in Ghana," J. Educ. Pract., vol. 7, no. 36, pp. 131-138, 2016, available at: Eric.ed.gov.

[10] G. Marela, A. Wahab, and C. R. Marchira, "Bullying verbal menyebabkan depresi remaja SMA Kota Yogyakarta," Ber. Kedokt. Masy., vol. 33, no. 1, p. 43, 2017, doi: 10.22146/bkm.8183.

[11] S. Mahmud, Z. Bin, A. Bakar, and H. B. Djaffri, "Bullying Type in Gender Perspective in Senior High School Students, South Sulawesi Province, Indonesia 2 . Bullying Type,” vol. 2, no. 2005, pp. 39-47, 2014, available at: Google Scholar.

[12] M. F. Shidiqi and V. Suprapti, "Pemaknaan Bullying pada Remaja Penindas ( The Bully )," J. Psikol. Kepribadian dan Sos., vol. 2, no. 2, pp. 90-98, 2013, available at: Google Scholar.

[13] Usman and Irvan, "Kepribadian, Komunikasi, Kelompok Teman Sebaya, Iklim Sekolah Dan Perilaku Bullying," Humanit. (Fakultas Psikol. Univ. Ahmad Dahlan), vol. 10, no. 1, pp. 49-60, 2013, doi: 10.26555/humanitas.v10i1.328.

[14] Y. P. Sari and W. Azwar, "Fenomena Bullying Siswa: Studi Tentang Motif Perilaku Bullying Siswa di SMP Negeri 01 Painan, Sumatera Barat," Ijtimaiyya J. Pengemb. Masy. Islam, vol. 10, no. 2, pp. 333367, 2018, doi: 10.24042/ijpmi.v10i2.2366. 
[15] D. A. Gentile and B. J. Bushman, "Reassessing media violence effects using a risk and resilience approach to understanding aggression.," Psychol. Pop. Media Cult., vol. 1, no. 3, pp. 138-151, 2012, doi: $10.1037 / \mathrm{a} 0028481$.

[16] E. Z. Zakiyah, S. Humaedi, and M. B. Santoso, "Faktor Yang Mempengaruhi Remaja Dalam Melakukan Bullying," Pros. Penelit. dan Pengabdi. Kpd. Masy., vol. 4, no. 2, pp. 324-330, 2017 , 10.24198/jppm.v4i2.14352.

[17] Masdin, "Fenomena Bullying Dalam Pendidikan," J. Al-Ta'dib, vol. 6, no. 2, pp. 73-83, 2013, doi: 10.31332/atdb.v6i2.306.

[18] Quinn and Ruairi, “Action Plan On Bullying: Report of the Anti-Bullying Working Group to the Minister for Education and Skills," no. January, p. 126, 2013, available at: Google Scholar.

[19] M. Muzaffar Syah, "School Bullying in Malaysia: Cause, Effect and A Possible Solution," Proc. SOCIOINT 2017 - 4th Int. Conf. Educ. Soc. Sci. Humanit., no. July, pp. 154-159, 2017. available at: Google Scholar.

[20] S. H. Kim and M. W. Telleen, "Talking about School Bullying: News Framing of Who Is Responsible for Causing and Fixing the Problem," Journal. Mass Commun. Q., vol. 94, no. 3, pp. 725-746, 2017, doi: $10.1177 / 1077699016655756$.

[21] S. Wachs, L. Bilz, S. Niproschke, and W. Schubarth, "Bullying Intervention in Schools: A Multilevel Analysis of Teachers' Success in Handling Bullying From the Students' Perspective," J. Early Adolesc., vol. 39, no. 5, pp. 642-668, 2019, doi: 10.1177/0272431618780423.

[22] F. Fithria, "Faktor-Faktor Yang Berhubungan Dengan Perilaku Bullying," Idea Nurs. J., vol. 7, no. 3, pp. 9-17, 2016, available at: Google Sholar.

[23] U. Ulfiah, "Penanganan Perilaku Bullying Siswa Melalui Konseling Model Pengembangan Komitmen Beragama," Psympathic J. Ilm. Psikol., vol. 1, no. 1, pp. 67-74, 2018, doi: 10.15575/psy.v1i1.2120.

[24] H. K. Al-Raqqad, E. S. Al-Bourini, F. M. Al Talahin, and R. M. E. Aranki, "The Impact of School Bullying On Students' Academic Achievement from Teachers Point of View," Int. Educ. Stud., vol. 10, no. 6, p. 44, 2017, available at: Eric.ed.gov. 